\title{
Chemical Changes and Heavy Metal Partitioning in an Oxisol Cultivated with Maize (Zea mays, L.) after 5 Years Disposal of a Domestic and an Industrial Sewage Sludge
}

\author{
S. Alcantara • D.V. Pérez • M. R. A. Almeida • \\ G.M. Silva • J.C. Polidoro $\cdot$ W. Bettiol
}

Received: 5 June 2008 / Accepted: 15 January 2009 / Published online: 5 February 2009

(C) Springer Science + Business Media B.V. 2009

\begin{abstract}
The need for solutions to minimize the negative environmental impacts of anthropogenic activities Fhas increased. Sewage sludge is composed of predominantly organic matter and can be used to improve soil characteristics, such as fertility. Therefore, its application in agriculture is an adequate alternative for its final disposal. However, there is a lack of information on its long-term effects on soil changes in tropical areas. Thus, the objectives of this study were to determine (i) the effect of sewage sludge application on heavy metal build-up in soil and maize grains and leaves, and (ii) the effects of soil amendment with sewage sludge on the chemical properties of a Brazilian oxisol. Besides the increasing levels of $\mathrm{Zn}$, $\mathrm{Cu}, \mathrm{Ni}$, and $\mathrm{Cr}$, amending soil with sewage sludge also alters the distribution of these metals by increasing the mobile Phases, which correlated significantly with the increase in metal extraction with two single extractants, Mehlich 1 and DTPA (Diethylene triamine
\end{abstract}

S. Alcantara $\cdot$ M. R. A. Almeida $\cdot$ G. Silva Instituto de Química, UFRJ, Av. Brigadeiro Trompovisky, $\mathrm{s} / \mathrm{n}$, Cidade Universitária,

CEP 21949-900 Rio de Janeiro (RJ), Brazil

D. Pérez $(\bowtie) \cdot J$. Polidoro

Embrapa Solos, R. Jardim Botânico, 1024, CEP 22460-000 Rio de Janeiro(RJ), Brazil e-mail: daniel@cnps.embrapa.br

W. Bettiol

Embrapa Meio Ambiente, Caixa Postal 69,

CEP 13820-000 Jaguariúna (SP), Brazil pentaacetic acid). The levels of $\mathrm{Fe}, \mathrm{Mn}, \mathrm{Zn}$, and $\mathrm{Cu}$ in maize grains and leaves increased with the type and rate of sewage sludge application. Nevertheless, metal build-up in soil and plants was within the allowed limits. Significant differences were also found in soil characteristics like humic fractionation with the applied sewage doses. The data obtained does not indicate any expressive drawbacks in the use of sewage sludge as a soil amendment, as the heavy metal concentrations observed are unlikely to cause any environmental or health problems, even overestimated loadings, and are in accordance with the Brazilian regulations on farming land biosolid disposal.

Keywords Humic substances · Sequential extraction · Metal accumulation

\section{Introduction}

The percentage of the Brazilian population served by sewage treatment has grown in the last years. In 2002, approximately 22 million inhabitants were connected to the sewage system. In 2005, this number rose to 25.5 million.

Sewage sludge, an inevitable by-product of wastewater treatment, contains high proportions of organic matter and plant nutrients (Wang 1997; McBride 2003; Sanchéz-Monedero et al. 2004). Thus, its use in the improvement of the physical and chemical 
properties of soil is recommended (Mantovi et al. 2005; Stabnikova et al. 2005). However, sewage sludge also contains contaminants, such as heavy metals, organic compounds, and excessive salts, which must also be considered in its agricultural use (Paramasivam et al. 2006). Heavy metals in sewage sludge may enter the food chain through crops and affect human health (Su and Wong 2003). Moreover, the physicochemical effects of the long-term use of sewage sludge in the amendment of tropical soils are still uncertain (Mbila et al. 2001; Oliveira et al. 2002; Udom et al. 2004).

Increased levels of $\mathrm{Cu}, \mathrm{Zn}, \mathrm{Cr}, \mathrm{Mo}, \mathrm{Ni}, \mathrm{Pb}$, and $\mathrm{Cd}$ have been observed in the oxisol surface layer $(0$ $20 \mathrm{~cm}$ ) in a field experiment in Jaguariúna, SP, Brazil due to soil amendment with varying quantities of sewage sludge from different sources since 1998 (Silva et al. 2006). This preliminary study shows the need for further information on the soil fraction distribution of these metals to evaluate their mobility, bioavailability and transference processes (D'Amore et al. 2005).

The complexity of soil chemical reactions generally restrains the studies on the distribution of metal species in the solid phase to operationally defined analytical procedures with the use of sequential extraction methods (Das et al. 1995; Morrow et al. 1996; Hayes \& Traina 1998). However, some procedures are time-consuming and normally present several problems (Candelaria \& Chang 1997; Sauve et al. 1998; Kot \& Namiesnik 2000). A single extractant is commonly used when it comes to soil fertility, but it has been applied in contamination studies as well (Mendonza et al. 2006; Kidd et al. 2007). Despite the simplicity of this technique, it is difficult to find an effective reagent for the selective extraction of the most bioavailable Phases of a specific metal; hence, the importance of such studies.

The main objective of this work was to study the impact of soil amendment with sewage sludge and the evolution of $\mathrm{Fe}, \mathrm{Mn}, \mathrm{Zn}, \mathrm{Ni}, \mathrm{Cu}, \mathrm{Cr}, \mathrm{Pb}$, and $\mathrm{Cd}$ as determined by sequential and single extractions with the two single extractants most used in Brazil (DPTA and Mehlich 1). The correlations between the sequential and single extractions and metal build-up in maize grains and leaves were also evaluated. A second goal was to evaluate the changes in certain soil properties, such as $\mathrm{pH}$, Cation Exchange Capacity (CEC), concentrations of organic carbon, $\mathrm{N}, \mathrm{S}$, and $\mathrm{P}$, as well as the humic fractioning of organic matter.

\section{Material and Methods}

\subsection{Field Experiment}

The experiment was factorial $(6 \times 2)$ in design with randomized blocks with three replications and was carried out in $20 \mathrm{X} 10-\mathrm{m}^{2}$ plots at Embrapa-CNPMA (latitude $22^{\circ} 41^{\prime} \mathrm{S}$, longitude $47^{\circ} \mathrm{W}$. Gr. and altitude $570 \mathrm{~m}$ ). The first factor consisted of six treatments: control, the mineral fertilization (NPK) recommended for maize, sewage sludge soil amendment with the same N concentration as that of NPK $(\mathrm{N})$, and two$(2 \mathrm{~N})$, four- $(4 \mathrm{~N})$, and eight-fold $(8 \mathrm{~N})$ the recommended $\mathrm{N}$ concentration in sewage sludge dose. The control treatment consisted of plots with no application of neither mineral fertilization nor sewage sludge. The experiment started in 1998 with an annual application of sewage sludge and the annual cultivation of maize. The quantities of sewage sludge applied between 1998 and 2002 are summarized in Table 1 as a function of the $\mathrm{N}$ concentration. The sewage sludge rates were calculated as a function of $\mathrm{N}$ available for maize, the study plant, considering a $\mathrm{N}$ mineralization rate of $30 \%$ (CETESB 1999). Supplementary K was applied whenever necessary in sewage sludge treatments. The other studied factor involved two kinds of sewage sludges: industrial, from the Barueri Wastewater Treatment Plant located in Metropolitan São Paulo, and domestic, from the Franca Wastewater Treatment Plant, located in the São Paulo State countryside. Barueri and Franca Wastewater Plants are activated sewage sludge treatment stations by complete mixing. The treatment process used in both plants, based on secondary level conventional activated sewage sludge, has an efficiency of removal of organic matter above $90 \%$, as measured by Biochemical Oxygen Demand (BOD). It comprises two phases: liquid and solid. The liquid phase unit comprises a distributing well and a final pumping station, mechanical medium screens, sand boxes, primary decanters, an aeration tank, and secondary decanters. The solid phase unit comprises gravity thickeners, flotation thickeners, digesters, sewage sludge chemical conditioning (iron chloride and cationic polymers), and three press-filters (mechanical dewatering). The main difference between the plants is that Barueri's plant is supplied by an industrial and household sewer system, while Franca's is supplied mainly by a 
Table 1 Mean analytical characteristics of the experimental sewage sludges from 1998 to 2002

\begin{tabular}{|c|c|c|c|c|c|c|c|c|c|c|c|}
\hline \multirow[t]{2}{*}{ Analysisa } & \multirow[t]{2}{*}{ Dry basis } & \multicolumn{2}{|l|}{1998} & \multicolumn{2}{|l|}{1999} & \multicolumn{2}{|l|}{2000} & \multicolumn{2}{|l|}{2001} & \multicolumn{2}{|l|}{2002} \\
\hline & & Barueri & Franca & Barueri & Franca & Barueri & Franca & Barueri & Franca & Barueri & Franca \\
\hline $\mathrm{P}$ & $\mathrm{g} \mathrm{kg}^{-1}$ & 15.9 & 16.0 & 31.2 & 21.3 & 26.9 & 12.9 & 17.7 & 13.8 & 17.9 & 27.3 \\
\hline K & $\mathrm{g} \mathrm{kg}^{-1}$ & 1.0 & 1.0 & 1.97 & 0.99 & 1.0 & 1.0 & 1.5 & 1.5 & 1.0 & 1.0 \\
\hline $\mathrm{Cd}$ & $\mathrm{mg} \mathrm{kg}^{-1}$ & 12.8 & 3.32 & 9.5 & 2.0 & 9.4 & 2.05 & 16.2 & 1.14 & 14.0 & 0.6 \\
\hline $\mathrm{Pb}$ & $\mathrm{mg} \mathrm{kg}^{-1}$ & 364.4 & 199.6 & 233 & 118 & 348.9 & 140.5 & 137.9 & 78.6 & 148.7 & 43.0 \\
\hline $\mathrm{Cu}$ & $\mathrm{mg} \mathrm{kg}^{-1}$ & 1,058 & 239.8 & 1,046 & 359 & 953.0 & 240.9 & 682.8 & 187.1 & 867.8 & 196.0 \\
\hline $\mathrm{Cr}$ & $\mathrm{mg} \mathrm{kg}^{-1}$ & 823.8 & 633.8 & 1,071 & 1,325 & $1,297.2$ & $1,230.3$ & 609.3 & 202.0 & 639.6 & 182.4 \\
\hline $\mathrm{Ni}$ & $\mathrm{mg} \mathrm{kg}^{-1}$ & 518.4 & 54.7 & 483 & 74 & 605.8 & 72.4 & 331.3 & 63.9 & 270.0 & 49.5 \\
\hline $\mathrm{Zn}$ & $\mathrm{mg} \mathrm{kg}^{-1}$ & 2,821 & 1,230 & 3,335 & 1,590 & 3,372 & 1,198 & $2,327.9$ & 773.0 & $3,330.0$ & 890.6 \\
\hline $\mathrm{Mn}$ & $\mathrm{mg} \mathrm{kg}^{-1}$ & 429.5 & 349.3 & 335 & 267 & 418.9 & 232.5 & 277.5 & 439.8 & 246.9 & 712.9 \\
\hline $\mathrm{Fe}$ & $\mathrm{mg} \mathrm{kg}^{-1}$ & 54,181 & 33,793 & 32,500 & 31,700 & 37,990 & 24,176 & 39,058 & 39,895 & 32,100 & 64,900 \\
\hline $\mathrm{OC}$ & $\mathrm{g} \mathrm{kg}^{-1}$ & 248.2 & 305.1 & 271 & 374 & 292.9 & 382.4 & 354.2 & 370.9 & 534.4 & 475.4 \\
\hline Humidity & $\%$ & 66.4 & 83 & 80.2 & 82.4 & 71.2 & 82.7 & 79.5 & 74.6 & 78.8 & 78.5 \\
\hline $\mathrm{N}$ & $\mathrm{g} \mathrm{kg}^{-1}$ & 21 & 56.4 & 49.7 & 67.5 & 42.1 & 68.2 & 50.8 & 49.7 & 79.7 & 57.7 \\
\hline S & $\mathrm{g} \mathrm{kg}^{-1}$ & 13.4 & 16.3 & 10.8 & 13.3 & 17.1 & 15.7 & 11.7 & 9.3 & 14.5 & 10.1 \\
\hline Loading ${ }^{b}$ & $\mathrm{~kg} \mathrm{ha}^{-1}$ & 8,095 & 3,014 & 3,995 & 3,504 & 5,315 & 3,766 & 5,295 & 4,432 & 3,200 & 4,300 \\
\hline
\end{tabular}

$O C$ organic carbon

${ }^{\text {a }}$ According to EPA 3051

${ }^{\mathrm{b}}$ Sewage application rate based on the nitrogen requirement of maize ( $\mathrm{N}$ treatment)

household sewer system. The Barueri's plant receives industrial discharges mainly from metallurgical, pharmaceutical, cosmetic, textile, and graphics industries. Both sewage sludges are suitable for agricultural application. All plots were cultivated with maize by the standard cultivation method. The soil was classified as typical clayey Haplustox. The physical and chemical characteristics of the surface layer $(0-20 \mathrm{~cm})$ before the onset of the study were: $\mathrm{pH}$ in water $=5.8$, Organic Matter $=25.5 \mathrm{~g} \mathrm{~kg}^{-1}, \mathrm{P}=$ $1.0 \mathrm{mg} \mathrm{kg}{ }^{-1}, \mathrm{~K}=0.1, \mathrm{Ca}=2.7, \mathrm{Mg}=0.8,=0.1, \mathrm{H}=3.5$, and $\mathrm{CEC}=7.3 \mathrm{cmol} \mathrm{kg}^{-1}$, and clay $=450 \mathrm{~g} \mathrm{~kg}^{-1}$. The soil was plowed with a disk plow (24") and a disk harrow (18") and rotary-tilled before planting for sewage sludge incorporation.

The soil was sampled in October 2002, approximately one week before sewage sludge application and one month before planting. The samples were collected at $0-20$ and $20-40 \mathrm{~cm}$ deep, dried in a forced air oven at $40{ }^{\circ} \mathrm{C}$, sieved with a $2-\mathrm{mm}$ mesh nylon sieve, and stored in polyethylene bags. Maize leaves were sampled for plant nutritional evaluation. They were lightly rinsed with a neutral detergent and distilled water, dried in a forced air oven at $70^{\circ} \mathrm{C}$, ground in a Wiley stainless steel mill, and sieved with a 1-mm nylon sieve. After harvesting in April 2003, the maize grains were also dried and ground. Ground grain samples were stored at room temperature in acid-washed polyethylene containers.

\subsection{Analytical Determinations}

Regarding the build-up of some metals observed in the 0-20 cm surface layer (Silva et al. 2006), a sequential extraction method (Wasserman et al. 2005) was used to determine metal associations in soil. The following phases were obtained: exchangeable + carbonate (P1), Fe-Mn oxide-bound (P2), organicbound (P3), Al oxide + strong Fe-Mn oxide-bound + organic recalcitrant (P4). The residual phase was made up of the unavailable Phase (P5).

The soils were also analyzed for routine determinations according to EMBRAPA (1997). Plant-available P was extracted by Mehlich $1\left(\mathrm{HCl} 0.05 \mathrm{~mol} \mathrm{~L}^{-1}+\right.$ $\mathrm{H}_{2} \mathrm{SO}_{4} 0.0125 \mathrm{~mol} \mathrm{~L}^{-1}$ ) and analyzed by spectrophotometry at $660 \mathrm{~nm}$. Soil $\mathrm{pH}$ was measured in a 1:2.5 soil:water suspension. Exchangeable $\mathrm{Ca}$ and $\mathrm{Mg}$ were extracted with $\mathrm{KCl} 1 \mathrm{~mol} \mathrm{~L}^{-1}$ and determined by complexometric titration with EDTA (Ethylenediamine tetraacetic acid). Exchangeable $\mathrm{Na}$ and $\mathrm{K}$ were extracted with Mehlich 1 and determined by flame photometry. $\mathrm{H}$ and exchangeable $\mathrm{Al}$ were extracted with calcium acetate $0.5 \mathrm{~mol} \mathrm{~L}^{-1}(\mathrm{pH}$ 7.0) and determined by acid-base titration. CEC was calculated 
by the sum of $\mathrm{Ca}, \mathrm{Mg}, \mathrm{Na}, \mathrm{K}, \mathrm{Al}$, and $\mathrm{H}$. Organic carbon was determined by oxidation with dichromate, and total N, with Kjeldahl. Available micronutrients ( $\mathrm{Fe}, \mathrm{Mn}, \mathrm{Zn}$, and $\mathrm{Cu}$ ) and heavy metals $(\mathrm{Cr}, \mathrm{Cd}, \mathrm{Pb}$, and $\mathrm{Ni}$ ) were extracted by Mehlich 1 and DTPA (pH 7.3) and determined by inductively coupled plasma optical emission spectrometry (ICP-OES, Perkin Elmer OPTIMA 3000). Sulfate was extracted with $\mathrm{Ca}$ $\left(\mathrm{H}_{2} \mathrm{PO}_{4}\right)_{2} 0.01 \mathrm{~mol} \mathrm{~L}^{-1}$ and determined by spectrophotometry at $420 \mathrm{~nm}$.

Grains and dry leaves of maize were digested with a nitric/perchloric acid mixture. The concentrations of the selected metals were determined by ICP-OES.

The humic fractions in soil were sequentially extracted according to Kononova and Bel'Chikova (Sastriques 1982) and as described elsewhere (Pérez et al. 2007).

Due to the lack of certified soil samples, to ensure the analytical quality of the sequential extraction protocol used in this work, we considered the total recovery obtained in this protocol, i.e., the sum of the five phases against aqua regia extraction of a certified reference material (BCR-701). The data were considered only when the recovery was above $75 \%$. For the plant material assays, SRM-1515 (apple leaves) was used as a certified reference and data were accepted when recovery was above $90 \%$. Moreover, a river water reference material, SLRS-4, was used to check ICP-OES calibrations. All soil and plant samples were extracted in duplicate.

Suprapure acids (Merck) and ultrapure water (Millipore ultrapure water system) were used in all laboratory procedures. All containers were soaked in $10 \% \mathrm{HNO}_{3}$ and thoroughly rinsed with deionized water before use.

Variance analysis was used to test the significance $(P<0.05)$ of treatment effects and the Tukey test $(P<$ $0.05)$ was used to compare the means. All statistical analyses were performed using Statistical Analysis System (SAS 2003).

\section{Results and Discussion}

\subsection{Soil Analysis}

\subsubsection{Chemical Analysis}

The influence of the use of sewage sludge as soil amendment in the studied doses was statistically significant for almost all soil parameters analyzed (Table 2).

The application of increasing sewage sludge rates raised the level of organic carbon in soil significantly at both $0-20$ and $20-40 \mathrm{~cm}$ deep, which probably affected soil CEC directly at both depths. The effect of the largest doses was significantly different compared to the others (Table 2). The large influence of organic matter on the chemical properties of soil is related to the alteration of its colloidal complex. It reflects the increase in negative surface charges (CEC), and consequently, the increase in cation retention (Zech et al. 1997; Abreu et al. 2005).

In relation to the average concentration of total $\mathrm{N}$, similar results were obtained on the surface layer, as expected, due to its close relation with the organic carbon in soil (Table 2). Nevertheless, at $20-40 \mathrm{~cm}$, no significant difference was observed (Table 2). Such a result is probably related to the combination of two causes. Besides the expected decrease in the

Table 2 Effect of the doses and type of sewage sludge used on the determination of $\mathrm{pH}, \mathrm{CEC}, \mathrm{OC}, \mathrm{N}, \mathrm{P}$, and sulfate in two depths of the Brazilian Oxisol studied

\begin{tabular}{|c|c|c|c|c|c|c|}
\hline Treatment & cmolc & $\mathrm{kg}^{-1}$ & $\begin{array}{l}\mathrm{OC} \\
\mathrm{g} \mathrm{kg}^{-1}\end{array}$ & $\begin{array}{l}\text { Parameter } \\
(N)\end{array}$ & $\begin{array}{l}P \\
\text { valuea } \\
\mathrm{mg} \mathrm{kg}^{-}\end{array}$ & $\begin{array}{l}\text { Sulfate } \\
-1\end{array}$ \\
\hline \multicolumn{7}{|l|}{$0-20 \mathrm{~cm}$} \\
\hline Control & $5.6 \mathrm{a}$ & $7.9 \mathrm{c}$ & $11.7 \mathrm{c}$ & $1.0 \mathrm{c}$ & $1 d$ & $22.99 b$ \\
\hline NPK & $5.5 \mathrm{a}$ & $8.1 \mathrm{c}$ & $12.1 \mathrm{c}$ & $1.0 \mathrm{c}$ & $10 \mathrm{~cd}$ & $27.18 b$ \\
\hline $\mathrm{N}$ & $5.6 \mathrm{a}$ & $8.5 \mathrm{c}$ & $12.4 \mathrm{c}$ & $1.1 \mathrm{bc}$ & $20 \mathrm{c}$ & $28.21 \mathrm{~b}$ \\
\hline $2 \mathrm{~N}$ & $5.3 \mathrm{a}$ & $8.6 b c$ & $13.4 \mathrm{bc}$ & $1.2 \mathrm{bc}$ & $31 \mathrm{c}$ & $36.40 \mathrm{ab}$ \\
\hline $4 \mathrm{~N}$ & $5.4 \mathrm{a}$ & $9.6 \mathrm{ab}$ & $14.6 b$ & $1.4 \mathrm{~b}$ & $66 b$ & $45.62 \mathrm{a}$ \\
\hline $8 \mathrm{~N}$ & $5.2 \mathrm{a}$ & $10.4 \mathrm{a}$ & $16.8 \mathrm{a}$ & $1.7 \mathrm{a}$ & $114 \mathrm{a}$ & $45.47 \mathrm{a}$ \\
\hline Franca & $5.5 \mathrm{a}$ & $8.6 b$ & $13.2 \mathrm{a}$ & $1.2 \mathrm{a}$ & $24 b$ & $30.86 \mathrm{~b}$ \\
\hline Barueri & $5.4 \mathrm{a}$ & $9.1 \mathrm{a}$ & $13.8 \mathrm{a}$ & $1.3 \mathrm{a}$ & $57 \mathrm{a}$ & $37.76 \mathrm{a}$ \\
\hline \multicolumn{7}{|c|}{$20-40 \mathrm{~cm}$} \\
\hline Control & $4.8 \mathrm{ab}$ & $6.8 b$ & $9.8 \mathrm{~b}$ & $0.8 \mathrm{a}$ & $1 \mathrm{c}$ & $31.40 \mathrm{c}$ \\
\hline NPK & $4.7 \mathrm{ab}$ & 7.3ab & $10.0 \mathrm{ab}$ & $0.8 \mathrm{a}$ & $1 \mathrm{c}$ & $36.25 \mathrm{c}$ \\
\hline $\mathrm{N}$ & $4.7 \mathrm{ab}$ & $7.3 \mathrm{ab}$ & $10.0 \mathrm{ab}$ & $0.8 \mathrm{a}$ & $6 b c$ & $54.54 b c$ \\
\hline $2 \mathrm{~N}$ & $4.7 \mathrm{ab}$ & $7.2 \mathrm{ab}$ & $10.3 \mathrm{ab}$ & $0.8 \mathrm{a}$ & $4 c$ & $52.59 \mathrm{c}$ \\
\hline $4 \mathrm{~N}$ & $4.8 \mathrm{a}$ & $7.9 \mathrm{a}$ & $10.5 \mathrm{ab}$ & $0.9 \mathrm{a}$ & $10 \mathrm{~b}$ & $95.42 \mathrm{ab}$ \\
\hline $8 \mathrm{~N}$ & $4.4 \mathrm{~b}$ & $8.0 \mathrm{a}$ & $11.1 \mathrm{a}$ & $1.0 \mathrm{a}$ & $23 a$ & $120.75 a$ \\
\hline Franca & $4.8 \mathrm{a}$ & $7.2 \mathrm{~b}$ & $10.2 \mathrm{a}$ & $0.8 \mathrm{a}$ & $5 b$ & $57.89 \mathrm{a}$ \\
\hline Barueri & $4.6 \mathrm{~b}$ & $7.6 \mathrm{a}$ & $10.3 \mathrm{a}$ & $0.9 \mathrm{a}$ & $9 \mathrm{a}$ & $72.43 a$ \\
\hline
\end{tabular}

Averages followed by different letters in the same column are statistically different by Tukey's test at $5 \%$ probability

$C E C$ cation exchange capacity, $O C$ organic carbon, $N$ nitrogen, $P$ phosphorus

${ }^{\text {a }}$ Variance analysis calculated with data transformed by $\sqrt{ }(x+1)$ 
activity of decomposing microorganisms with depth (Cattelan \& Vidor 1990; Fialho et al. 1991; Fernandes et al. 2005), the absolute content of organic matter in soil also decreased. Together, they led to less $\mathrm{N}$ buildup. The sewage sludge doses influenced the content of $\mathrm{P}$ significantly, increasing its availability in the soil at the two studied depths (Table 2). This was already expected, since the original $\mathrm{P}$ content in the soil was very low, which corroborates the studies of Oliveira et al. (2002) and Rocha et al. (2004).

The sewage sludge doses influenced the $\mathrm{pH}$ of the soil significantly only at $20-40 \mathrm{~cm}$ (Table 2 ). The largest sewage sludge dose applied $(8 \mathrm{~N})$ consistently led to a significant reduction of the soil $\mathrm{pH}$ (Table 2), which may be attributed especially to the lixiviation of the organic acid produced in the microbiological decomposition of organic matter of sewage sludge (Brofas et al. 2000). Studies of more acidic soils also reported a decline in soil $\mathrm{pH}$ with the application of sewage sludge. Obbard et al. (1993) worked with two groups of soils with similar textures, one with low $\mathrm{pH}$ (4.8-5.8) and another with higher $\mathrm{pH}$ (5.0-7.0). In both soils, $\mathrm{pH}$ decreased due to the use of sewage sludge, which was attributed to the nitrification of the organic residue. The lack of significance of the variation of $\mathrm{pH}$ in the surface soil layer (Table 2) can be explained by the liming acidity control carried out in 2001.

Regarding the type of sewage sludge applied, the largest contents of $\mathrm{P}$ at both depths were obtained with Barueri's sewage sludge (Table 2), since it has the largest quantity of P (Table 1). Furthermore, CEC was higher in soils treated with Barueri's sewage sludge at both depths, probably due to its large quantity of organic matter (Table 1). However, the results of organic carbon in soil were not statistically significant (Table 2). The same $\mathrm{pH}$ behavior was observed in the surface soil layer $(0-20 \mathrm{~cm})$, probably without significant differences due to the liming conducted in 2001 . In contrast, the low $\mathrm{pH}$ of the deep layer of soils treated with Barueri's sewage sludge is related to the larger quantity of sewage sludge loaded in these soils (Table 1), which probably reduced the $\mathrm{pH}$ through mineralization and lixiviation of organic acids.

\subsubsection{Mehlich 1 and DTPA Extractions}

The concentrations of $\mathrm{Mn}, \mathrm{Zn}, \mathrm{Cr}$, and Ni extracted with Mehlich 1 were high, in contrast with that of
$\mathrm{Pb}$. The concentration of $\mathrm{Pb}$ was higher in the extraction with DTPA. The concentrations of Fe, $\mathrm{Cu}$, and $\mathrm{Cd}$ obtained with both extractants were similar (Table 3). Apparently, both extractants respond directly and proportionally to the amounts of the elements introduced after the application of sewage sludge. However, DTPA has a greater discriminating power for $\mathrm{Pb}$, while Mehlich 1 described the behavior of $\mathrm{Cr}$ better.

Abreu et al. (2005) tested farmland soil samples collected from 1993 to 1999 by massive routine DTPA. Their database may be useful in the assessment of excess heavy metals in Brazilian croplands. Based on the third percentile as an indicator of potential heavy metal threat, in general, the high concentrations observed at $0-20 \mathrm{~cm}$ occurred after the application of $2 \mathrm{~N}$ sewage sludge. However, considering the heavy metal concentration obtained after the application of each type of sewage, the application of Barueri's sewage sludge, even in the recommended amount, $(\mathrm{N})$, led to high concentrations of $\mathrm{Zn}, \mathrm{Ni}, \mathrm{Cd}$, and $\mathrm{Pb}\left(5.98,0.23,0.026,1.04 \mathrm{mg} \mathrm{kg}^{-1}\right.$, respectively) at $0-20 \mathrm{~cm}$. At $20-40 \mathrm{~cm}$, only the concentrations of $\mathrm{Zn}\left(4.35 \mathrm{mg} \mathrm{kg}^{1}\right)$ above $4 \mathrm{~N}$ and $\mathrm{Ni}$ and $\mathrm{Cd}(0.85$ and $0.035 \mathrm{mg} \mathrm{kg}^{-1}$, respectively) for $8 \mathrm{~N}$ were higher than those reported by Abreu et al. (2005).

The different concentrations of the analyzed metals at 20-40 cm deep (Table 3) possibly reflect a certain mobility of these elements, which was also observed by many other authors (Tiller 1989; Giusquiani et al. 1992; Mbila et al. 2001; McLaren et al. 2005; Toribio \& Romanya 2006; Antoniadis 2008). In support of this hypothesis, the organic carbon content is influenced by the doses of sewage sludge at depth (Table 2), indicating a possible mobility of organic complexes accountable for the mobilization of metals at depth (Strobel 2001; Tipping 2002; Tan 2003). Additionally, sulfate may also have contributed to this mobility. Its concentration increased significantly in both layers, $0-20$ and $20-40 \mathrm{~cm}$, (Table 2) relative to the doses and the type of sewage sludge applied. It is well known (Stumm and Morgan 1996) that some of the studied elements, such as $\mathrm{Zn}$, can form ionic pairs with sulfate, which may promote its lixiviation through the soil profile. An analog behavior has already been reported for gypsum $\left(\mathrm{CaSO}_{4}\right)$ concerning the capacity of sulfate to form ionic pairs with $\mathrm{Al}$ and $\mathrm{Mg}$, mobilizing both to deeper soil layers (Alva et al. 1991; de Maria et al. 1993). 


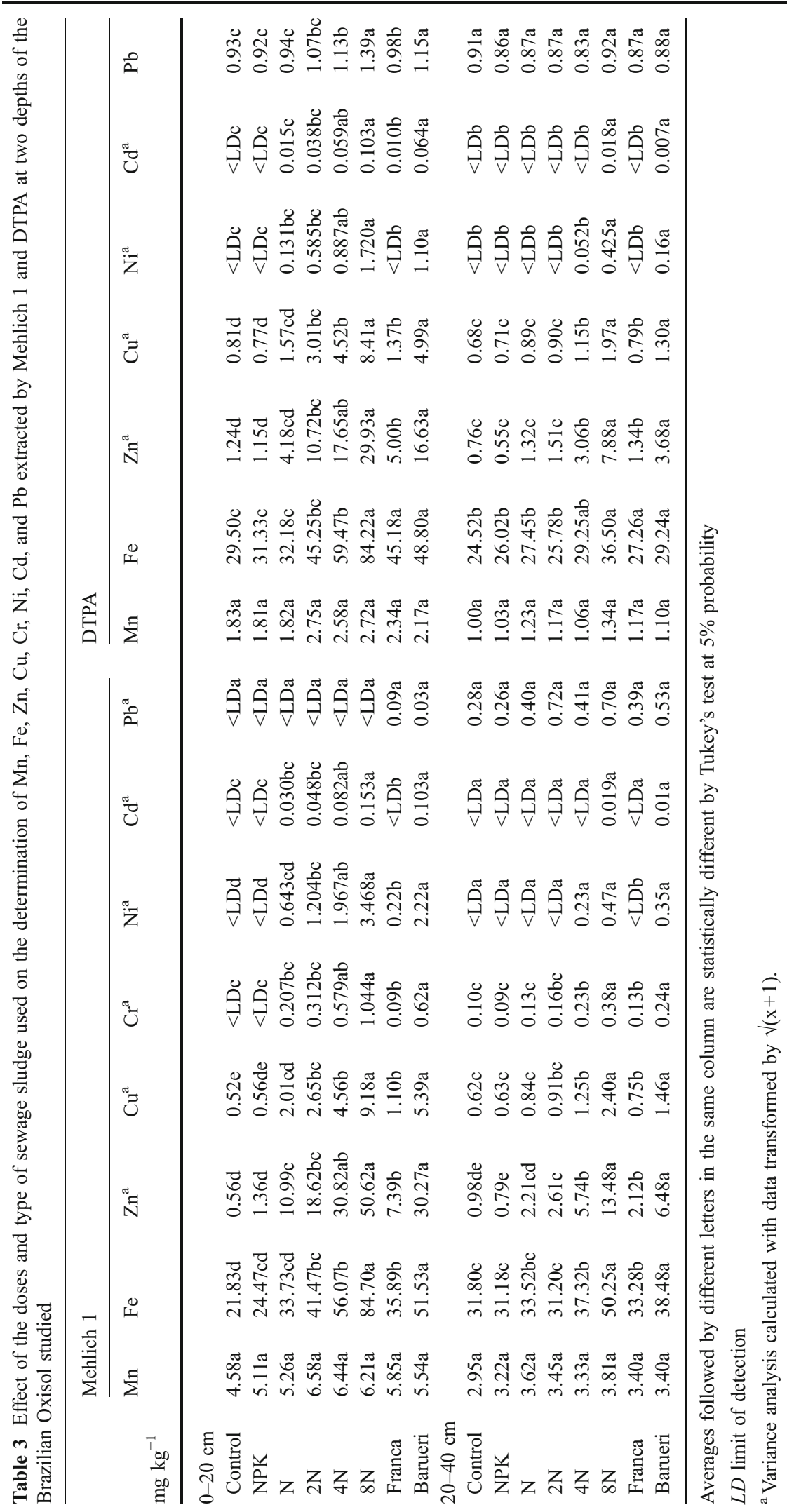


DTPA and Mehlich 1 extraction data of the studied metals regarding the type of applied sewage sludge are also presented in Table 3. Apart from the type of extractant, significant differences are associated with large contents of trace metals in Barueri's sewage sludge, which is under larger industrial influence and, therefore, has the highest concentration of the analyzed metals (Table 1).

\subsubsection{Sequential Extraction}

The binding form of the metals in the solid phase of the soil is related to the intensity of their release to the liquid phase, and hence, the likelihood of their mobilization and bioavailability (Perez et al. 2007).
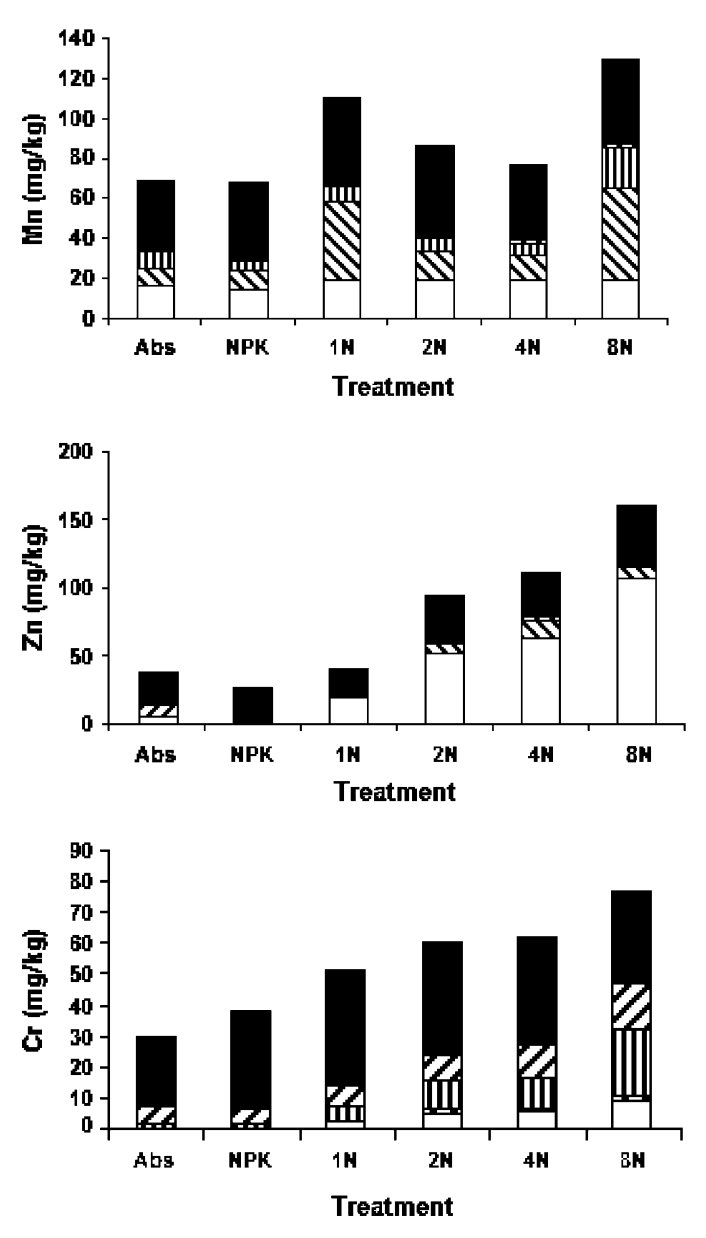

$\square$ Phase 1 DPhase 2 mPhase 3 ØPhase 4 - Phase 5

Fig. 1 Concentrations of $\mathrm{Mn}, \mathrm{Fe}, \mathrm{Zn}, \mathrm{Cu}, \mathrm{Cr}$, and $\mathrm{Ni}$ in solid-phase components of soils amended treated with sewage sludge from Barueri Plant
In the sequential extraction scheme used in this work, Phases 1-3 were more likely to represent the equilibrium between the liquid and the solid phases than Phases 4 and 5. Presumably, they have more structurally bound elements occluded in $\mathrm{Fe}$ and $\mathrm{Mn}$ oxides and are strongly adsorbed by $\mathrm{Al}$ oxides and residual silicates.

All of the elements behaved similarly in the experiments with sewage sludge from either Franca or Barueri plants applied to the soil. For this reason, only the graphs for Barueri's sewage sludge are shown (Fig. 1), as it is potentially more dangerous to the environment due to its higher concentrations of heavy metals (Table 1). Although $\mathrm{Cu}$ occurs in different soil Phases, it tends to bind to the organic matter (Phase 3 ) and the exchangeable Phase (Phase 1) with the increase in
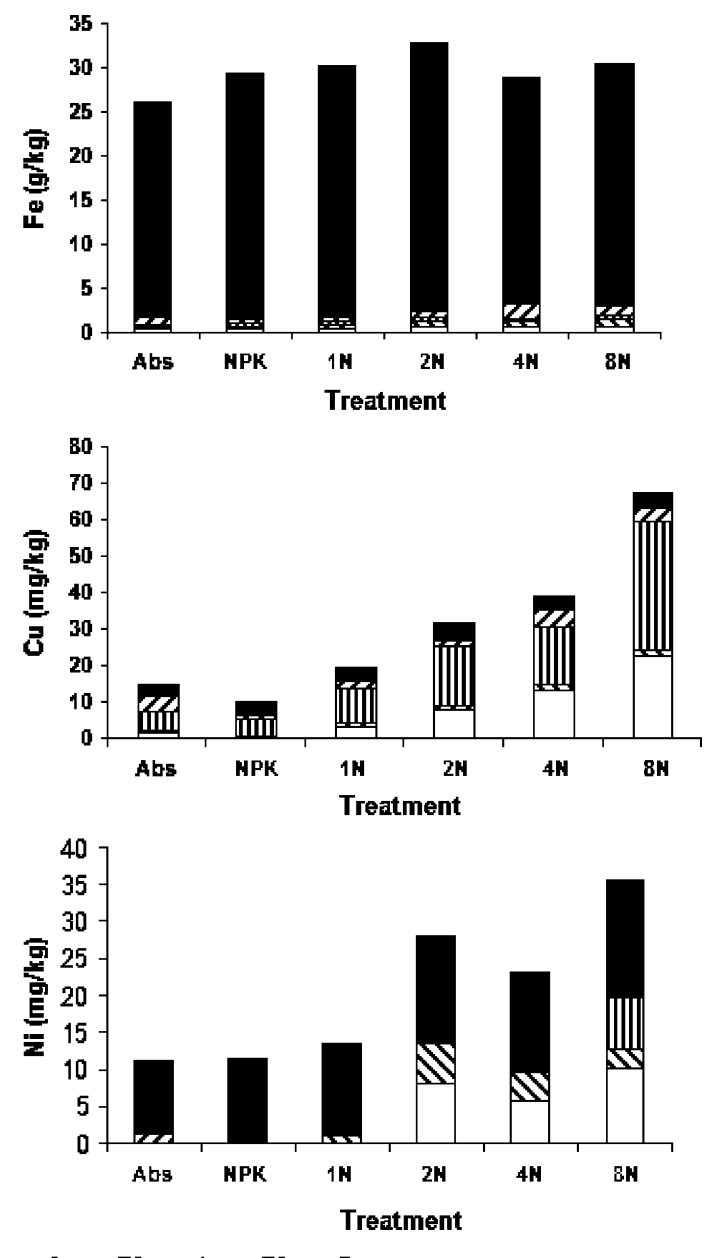
applied sewage sludge dose. Cr tends to concentrate in the residual Phase (Phase 5). However, it also appears in Phases 1, 3 and 4 (strong oxide-bound/organic matter-occluded Phase) with increasing sewage sludge doses rather than in Phase 5. Increasing doses of sewage sludge caused a large increase in $\mathrm{Zn}$ in Phase 1 , and a slight increase in Phase 2 (oxide Phase) as well. Originally, Ni tends to concentrate in Phase 5. However, increasing the doses of sewage sludge applied raised its concentration in Phases 1 and 3 but only in high doses for the latter. Due to the low original total concentrations of $\mathrm{Cd}$ and $\mathrm{Pb}$ (Silva et al. 2006), the sequential extraction probably reduced their concentrations in the five extracted phases, rendering many of the determinations below the limit of detection of the analytic method. On the whole, the application of increasing doses of sewage sludge led to an increase in the bioavailable concentrations of $\mathrm{Zn}$, $\mathrm{Cu}, \mathrm{Cr}$, and $\mathrm{Ni}$ (Phases 1, 2, and 3), indicating a potential risk of contamination.

\subsubsection{Comparison of Simple and Sequential Extractions $(0-20 \mathrm{~cm})$}

A correlation matrix was made to evaluate the possible relation between single extractions with Mehlich 1 and DTPA solutions and the phases of sequential extraction (Table 4). In general, all of the determined elements in both single extractants presented very significant $(P<0.01)$ correlation coefficients $(r)$, especially with Phase 1 , which is the most bioavailable Phase in the soil, such as reported by Hseu (2006). His data showed significant positive correlation $\left(R^{2}=0.96\right)$ between the $\mathrm{Zn}$ concentrations obtained by DTPA extraction and the sum of the exchangeable (P1) and the carbonate-bound (P2) Phase results obtained by the sequential extraction, which are equivalent to Phase 1 values in the present work. It is still worth pointing out that the coefficient of correlation of Phase 3 (phase related to the organic matter) with $\mathrm{Cu}$, an element clearly related to soil humic substances (Kabata Pendias and Pendias 2001; Ashworth and Alloway 2007), is also very significant.

Some of the results described below for each type of sewage sludge (Table 4) are in contrast with the above general evaluation. The extraction of Mn by DTPA only correlated significantly in samples of soil treated with Franca's sewage sludge, particularly with Phase 4. In the case of $\mathrm{Cu}$, soil samples treated with Franca's sewage sludge correlated more strongly with Phase 3 for both single extractants. However, the extraction of Cr with Mehlich 1 and Phase 4 showed the highest correlation coefficient.

\subsubsection{Humic Fractions}

Figure 2a shows that the organic carbon content of the two types of sewage sludge did not vary significantly, similar to the fulvic acid and humic acid fractions, although the results of Barueri's sewage sludge was slightly lower than that of Franca's. Nevertheless, the humin fraction was clearly different for both types of sewage sludge with a higher concentration in Franca's. Hence, the total humic fraction (fulvic + humic + humin) in Franca's sewage sludge was higher than in Barueri's. Consequently, the nonhumic fraction was significantly higher in Barueri's (Fig. 2a).

The fulvic acid concentration in the soil was influenced by the type of sewage sludge applied, but not by its dose (Table 5). Despite the slight difference between the two types of sewage sludge (Fig. 2a), the one with higher absolute content of fulvic acid (Barueri's) influenced its build-up in the treated soil (Table 5). Humic acid followed the same pattern as that of fulvic acid. Its concentration varied only with the type of sewage sludge applied to the soil, which was higher in soils treated with Barueri's sewage sludge as it has a higher absolute content of humic acid (Fig. 2a and Table 5). These results apparently corroborate the findings already reported for CEC (Table 2), as fulvic and humic acids are the main contributors to CEC. Thus, the significantly larger contribution of these humic fractions in soils treated with Barueri's sewage sludge reflects the significantly higher CEC of these soils, although the soils did not show any significant difference in organic carbon contents (Table 2) relative to the type of sewage sludge used in soil amendment.

The concentration of humin in the soil was influenced by the type and dose of sewage sludge applied to the soil. Once more, the soils treated with Franca's sewage sludge had higher humin content (Fig. 2a and c), in contrast to the ones treated with Barueri's (Fig. 2b and d). The significant increase in soil humin with increasing rates of applied sewage sludge was expected, as it was the main fraction in the sewage sludge applied (Fig. 2a and c). Moreover, some authors (Shevtsova 1972; Kononova 1984) observed 
Table 4 Linear correlation coefficients $(r)$ between $\mathrm{Mn}, \mathrm{Fe}, \mathrm{Zn}, \mathrm{Cu}, \mathrm{Cr}$, and $\mathrm{Ni}$ determined in the sequential extraction and extracted by Mehlich 1 and DTPA considering all data or the type of sewage sludge used

\begin{tabular}{|c|c|c|c|c|c|c|c|c|c|}
\hline Sewage & Extractant & Phase 1 & Phase 2 & Phase 3 & Phase 4 & Phase 5 & $\mathrm{P} 1+\mathrm{P} 2$ & $\mathrm{P} 1+\mathrm{P} 3$ & $\mathrm{P} 1+\mathrm{P} 2+\mathrm{P} 3$ \\
\hline \multicolumn{10}{|l|}{$\mathrm{Mn}$} \\
\hline Franca & Mehlich 1 & $0.92 * *$ & 0.58 & 0.20 & 0.75 & 0.18 & 0.79 & 0.42 & 0.68 \\
\hline Franca & DTPA & 0.73 & 0.30 & 0.26 & $0.86^{*}$ & 0.34 & 0.53 & 0.43 & 0.59 \\
\hline Barueri & Mehlich 1 & 0.83 & 0.23 & 0.28 & 0.57 & 0.42 & 0.31 & 0.51 & 0.32 \\
\hline Barueri & DTPA & 0.72 & 0.29 & 0.47 & 0.49 & 0.44 & 0.36 & 0.64 & 0.41 \\
\hline All & Mehlich 1 & $0.88 * *$ & 0.17 & 0.26 & $0.66^{*}$ & 0.20 & 0.32 & 0.47 & 0.39 \\
\hline All & DTPA & $0.73 * *$ & 0.15 & 0.35 & $0.71 * *$ & 0.24 & 0.28 & 0.52 & 0.41 \\
\hline \multicolumn{10}{|l|}{$\mathrm{Fe}$} \\
\hline Franca & Mehlich 1 & $0.97 * *$ & 0.42 & 0.74 & $0.95 * *$ & -0.17 & 0.71 & $0.93 * *$ & 0.72 \\
\hline Franca & DTPA & $0.98 * *$ & 0.46 & 0.77 & $0.95^{* *}$ & -0.16 & 0.75 & $0.95^{* *}$ & 0.76 \\
\hline Barueri & Mehlich 1 & $0.96 * *$ & 0.82 & $0.88^{*}$ & 0.48 & 0.14 & $0.89^{*}$ & $0.95 * *$ & $0.91 *$ \\
\hline Barueri & DTPA & $0.95 * *$ & 0.81 & $0.86^{*}$ & 0.49 & 0.06 & $0.88^{*}$ & $0.93 * *$ & $0.90 *$ \\
\hline All & Mehlich 1 & $0.96^{* *}$ & 0.75 & $0.83^{* *}$ & 0.32 & 0.17 & $0.87 * *$ & $0.93 * *$ & $0.88 * *$ \\
\hline All & DTPA & $0.86^{* *}$ & $0.66^{*}$ & $0.65^{*}$ & $0.59 *$ & 0.01 & $0.77 * *$ & $0.79 * *$ & $0.76 * *$ \\
\hline \multicolumn{10}{|l|}{$\mathrm{Zn}$} \\
\hline Franca & Mehlich 1 & $0.99 * *$ & -0.53 & - & $0.84 *$ & 0.09 & 0.71 & $0.99 * *$ & 0.71 \\
\hline Franca & DTPA & $0.98 * *$ & -0.44 & - & $0.85^{*}$ & 0.15 & 0.77 & $0.98 * *$ & 0.77 \\
\hline Barueri & Mehlich 1 & $0.99 * *$ & 0.74 & - & -0.17 & $0.90 *$ & $0.99 * *$ & $0.99 * *$ & $0.99 * *$ \\
\hline Barueri & DTPA & $0.99 * *$ & 0.74 & - & -0.13 & $0.93 * *$ & $0.99 * *$ & $0.99 * *$ & $0.99 * *$ \\
\hline All & Mehlich 1 & $0.99 * *$ & 0.43 & - & -0.05 & 0.10 & $0.98 * *$ & $0.99 * *$ & $0.98 * *$ \\
\hline All & DTPA & $0.99 * *$ & 0.46 & - & -0.01 & 0.16 & $0.98 * *$ & $0.99 * *$ & $0.98 * *$ \\
\hline \multicolumn{10}{|l|}{$\mathrm{Cu}$} \\
\hline Franca & Mehlich 1 & $0.86^{*}$ & 0.45 & $0.98 * *$ & $0.96^{* *}$ & 0.61 & $0.90 *$ & $0.99 * *$ & $0.96 * *$ \\
\hline Franca & DTPA & $0.84^{*}$ & 0.45 & $0.98 * *$ & $0.96^{* *}$ & 0.58 & $0.89^{*}$ & $0.98 * *$ & $0.96 * *$ \\
\hline Barueri & Mehlich 1 & $0.99 * *$ & 0.70 & $0.98 * *$ & 0.38 & 0.71 & $0.99 * *$ & $0.99 * *$ & $0.99 * *$ \\
\hline Barueri & DTPA & $1.00 * *$ & 0.72 & $0.99 * *$ & 0.40 & 0.73 & $0.99 * *$ & $1.00 * *$ & $1.00 * *$ \\
\hline All & Mehlich 1 & $0.98 * *$ & 0.23 & $0.98 * *$ & 0.23 & $0.66^{*}$ & $0.98 * *$ & $0.99 * *$ & $0.99 * *$ \\
\hline All & DTPA & $0.99 * *$ & 0.25 & $0.99 * *$ & 0.25 & $0.67 *$ & $0.99 * *$ & $1.00 * *$ & $0.99 * *$ \\
\hline \multicolumn{10}{|l|}{$\mathrm{Cr}$} \\
\hline Franca & Mehlich 1 & 0.81 & - & $0.90 *$ & $0.95 * *$ & 0.35 & 0.81 & $0.88 *$ & $0.88 *$ \\
\hline Franca & DTPA & - & - & - & - & - & - & - & - \\
\hline Barueri & Mehlich 1 & $0.96^{* *}$ & 0.81 & $0.97 * *$ & $0.99 * *$ & 0.19 & $0.95^{* *}$ & $0.98 * *$ & $0.98 * *$ \\
\hline Barueri & DTPA & - & - & - & - & - & - & - & - \\
\hline All & Mehlich 1 & $0.92 * *$ & $0.85^{* *}$ & $0.95^{* *}$ & $0.77 * *$ & 0.42 & $0.93 * *$ & $0.95 * *$ & $0.96^{* *}$ \\
\hline All & DTPA & - & - & - & - & - & - & - & - \\
\hline \multicolumn{10}{|l|}{$\mathrm{Ni}$} \\
\hline Franca & Mehlich 1 & - & 0.80 & - & - & -0.06 & 0.80 & - & 0.80 \\
\hline Franca & DTPA & - & - & - & - & - & - & - & - \\
\hline Barueri & Mehlich 1 & $0.89^{*}$ & 0.54 & 0.83 & -0.45 & $0.90 *$ & 0.82 & $0.95 * *$ & $0.93 * *$ \\
\hline Barueri & DTPA & $0.91^{*}$ & 0.52 & $0.85^{*}$ & -0.40 & $0.87 *$ & 0.82 & $0.97 * *$ & $0.94 * *$ \\
\hline All & Mehlich 1 & $0.92 * *$ & $0.67 *$ & $0.82 * *$ & -0.20 & $0.89 * *$ & $0.88^{* *}$ & $0.96^{* *}$ & $0.95 * *$ \\
\hline All & DTPA & $0.94 * *$ & $0.63 *$ & $0.85 * *$ & -0.16 & $0.88^{* *}$ & $0.87 * *$ & $0.98 * *$ & $0.95 * *$ \\
\hline
\end{tabular}

$* P<0.05, * * P<0.01$

that the use of soil for cultivation increased the content of humin in soil as well. Other authors (Canellas et al. 2001; Pérez et al. 2007) found an increase in humin content due to soil amendment with urban wastes.
The data suggest that the various types of sewage sludge affected the soils differently, with distinct distributions of the humic fractions and the related soil characteristics, like CEC. 
Fig. 2 Organic carbon content of the humic fractions of a the two types of sewage sludge used, b the soils considering the two types of sewage sludge used, $\mathbf{c}$ the two types of sewage sludge used, percentage basis, $\mathbf{d}$ the soils considering the two types of sewage sludge used, percentage basis
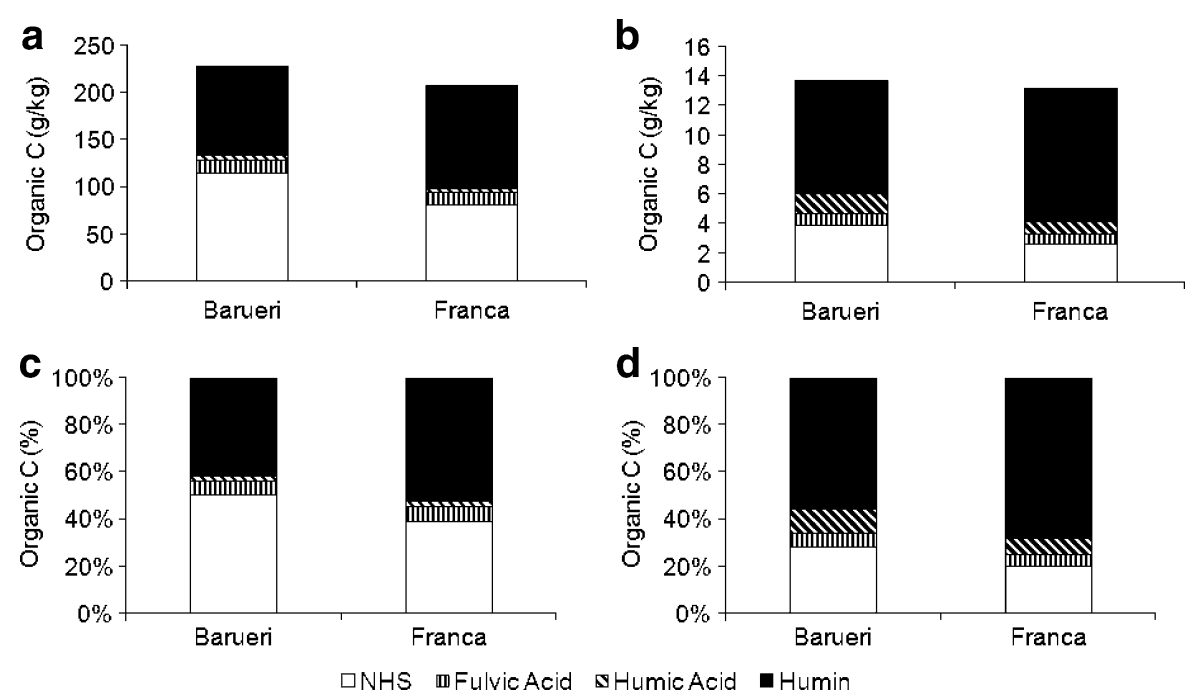

\subsection{Plant Analysis}

The results obtained for maize grains and leaves according to the types and doses of sewage sludge are found in Table $6 . \mathrm{Cd}, \mathrm{Cr}, \mathrm{Ni}$, and $\mathrm{Pb}$, were normally below the limit of detection of ICP-OES. However, treatment $8 \mathrm{~N}$ with Barueri's sewage sludge afforded $\mathrm{Ni}$ and $\mathrm{Cd}$ concentrations in leaves and $\mathrm{Ni}$ in grains of $0.52,0.058$, and $1.86 \mathrm{mg} \mathrm{kg}^{-1}$, respectively. Treatment $4 \mathrm{~N}$, with Barueri's sewage sludge, yielded a detectable concentration of $\mathrm{Ni}$ in grain $0.72 \mathrm{mg} \mathrm{kg}^{-1}$.

When the concentration of one of the analyzed metals was significantly different in either grains or

Table 5 Effect of the doses and type of sewage sludge used in the humic matter chemical fractionation of the topsoil $(0-$ $20 \mathrm{~cm}$ ) of the Brazilian Oxisol studied

\begin{tabular}{llllll}
\hline Treatment & $\begin{array}{l}\text { Fulvic } \\
\text { acid } \\
\mathrm{g} \mathrm{kg}^{-1}\end{array}$ & $\begin{array}{l}\text { Humic } \\
\text { acid }\end{array}$ & Humin & $\begin{array}{l}\text { Humic } \\
\text { substance }\end{array}$ & $\begin{array}{l}\text { Non-humic } \\
\text { substance }\end{array}$ \\
\hline Control & $0.55 \mathrm{a}$ & $0.84 \mathrm{a}$ & $7.21 \mathrm{~b}$ & $8.59 \mathrm{~b}$ & $3.08 \mathrm{ab}$ \\
$\mathrm{NPK}$ & $0.70 \mathrm{a}$ & $1.00 \mathrm{a}$ & $7.12 \mathrm{~b}$ & $8.81 \mathrm{~b}$ & $3.26 \mathrm{ab}$ \\
$\mathrm{N}$ & $0.74 \mathrm{a}$ & $1.09 \mathrm{a}$ & $8.11 \mathrm{ab}$ & $9.93 \mathrm{ab}$ & $2.50 \mathrm{ab}$ \\
$2 \mathrm{~N}$ & $0.75 \mathrm{a}$ & $1.20 \mathrm{a}$ & $9.03 \mathrm{ab}$ & $10.98 \mathrm{ab}$ & $2.40 \mathrm{~b}$ \\
$4 \mathrm{~N}$ & $0.78 \mathrm{a}$ & $1.31 \mathrm{a}$ & $8.80 \mathrm{ab}$ & $10.89 \mathrm{ab}$ & $3.73 \mathrm{ab}$ \\
$8 \mathrm{~N}$ & $0.80 \mathrm{a}$ & $1.44 \mathrm{a}$ & $9.72 \mathrm{a}$ & $11.96 \mathrm{a}$ & $4.87 \mathrm{a}$ \\
Franca & $0.65 \mathrm{~b}$ & $0.86 \mathrm{~b}$ & $9.03 \mathrm{a}$ & $10.54 \mathrm{a}$ & $2.69 \mathrm{~b}$ \\
Barueri & $0.79 \mathrm{a}$ & $1.43 \mathrm{a}$ & $7.64 \mathrm{~b}$ & $9.86 \mathrm{a}$ & $3.92 \mathrm{a}$ \\
\hline
\end{tabular}

Averages followed by different letters in the same column are statistically different by Tukey's test at $5 \%$ probability leaves, generally, the highest concentrations were associated with the industrial sewage sludge of Barueri (Table 1).

Regarding the sewage sludge doses (Table 6), the concentrations of $\mathrm{Mn}, \mathrm{Fe}, \mathrm{Zn}$, and $\mathrm{Cu}$ in grains were lower than those in leaves, which was expected due to physiological barriers for the migration of metals to

Table 6 Average $\mathrm{Fe}, \mathrm{Mn}, \mathrm{Zn}$, and $\mathrm{Cu}$ contents in maize (grain and leaves) considering the doses and types of sewage sludge used

\begin{tabular}{lllll}
\hline Treatment & $\begin{array}{l}\text { Mn } \\
\mathrm{mg} \mathrm{kg}^{-1}\end{array}$ & & $\mathrm{Zn}$ & $\mathrm{Cu}$ \\
& & & & \\
Grain & & & & \\
Control & $7.84 \mathrm{~b}$ & $22.22 \mathrm{c}$ & $32.38 \mathrm{c}$ & $1.78 \mathrm{a}$ \\
$\mathrm{NPK}$ & $9.51 \mathrm{ab}$ & $25.65 \mathrm{bc}$ & $30.70 \mathrm{c}$ & $1.66 \mathrm{a}$ \\
$\mathrm{N}$ & $9.65 \mathrm{ab}$ & $26.55 \mathrm{bc}$ & $35.67 \mathrm{c}$ & $1.73 \mathrm{a}$ \\
$2 \mathrm{~N}$ & $10.96 \mathrm{a}$ & $28.82 \mathrm{abc}$ & $37.48 \mathrm{bc}$ & $1.73 \mathrm{a}$ \\
$4 \mathrm{~N}$ & $11.70 \mathrm{a}$ & $34.15 \mathrm{ab}$ & $47.33 \mathrm{ab}$ & $1.83 \mathrm{a}$ \\
$8 \mathrm{~N}$ & $10.60 \mathrm{a}$ & $36.75 \mathrm{a}$ & $51.05 \mathrm{a}$ & $1.66 \mathrm{a}$ \\
Franca & $9.99 \mathrm{a}$ & $28.13 \mathrm{a}$ & $35.72 \mathrm{~b}$ & $1.72 \mathrm{a}$ \\
Barueri & $10.10 \mathrm{a}$ & $29.92 \mathrm{a}$ & $42.48 \mathrm{a}$ & $1.74 \mathrm{a}$ \\
Leaves & & & & \\
Control & $26.45 \mathrm{~b}$ & $59.52 \mathrm{c}$ & $18.52 \mathrm{~d}$ & $7.46 \mathrm{~b}$ \\
NPK & $27.70 \mathrm{~b}$ & $66.28 \mathrm{bc}$ & $19.47 \mathrm{~d}$ & $7.89 \mathrm{ab}$ \\
$\mathrm{N}$ & $27.83 \mathrm{~b}$ & $71.43 \mathrm{ab}$ & $28.65 \mathrm{~cd}$ & $8.00 \mathrm{ab}$ \\
$2 \mathrm{~N}$ & $32.00 \mathrm{ab}$ & $74.15 \mathrm{ab}$ & $33.28 \mathrm{c}$ & $8.42 \mathrm{ab}$ \\
$4 \mathrm{~N}$ & $31.73 \mathrm{~b}$ & $76.30 \mathrm{a}$ & $54.77 \mathrm{~b}$ & $9.12 \mathrm{a}$ \\
$8 \mathrm{~N}$ & $43.80 \mathrm{a}$ & $69.67 \mathrm{ab}$ & $102.48 \mathrm{a}$ & $8.77 \mathrm{a}$ \\
Franca & $33.91 \mathrm{a}$ & $71.19 \mathrm{a}$ & $30.36 \mathrm{~b}$ & $8.47 \mathrm{a}$ \\
Barueri & $29.27 \mathrm{~b}$ & $67.93 \mathrm{a}$ & $55.37 \mathrm{a}$ & $8.08 \mathrm{a}$ \\
\hline Averag & & & &
\end{tabular}

Averages followed by different letters in the same column are statistically different by Tukey's test at $5 \%$ probability 
grains (Shaw 1989; Kidd et al. 2007). However, it is worth noting that the concentration of $\mathrm{Ni}$ was the highest in Barueri's sewage sludge $(8 \mathrm{~N})$ and was higher in grains $\left(1.86 \mathrm{mg} \mathrm{kg}^{-1}\right)$ than in leaves $\left(0.72 \mathrm{mg} \mathrm{kg}^{-1}\right)$. The concentrations of $\mathrm{Mn}, \mathrm{Fe}$, and $\mathrm{Zn}$ increased in grains with the increase in the sewage sludge dose as well.

Concerning the metals in leaves, the concentrations of all the four determined elements increased significantly with the sewage sludge dose.

\subsubsection{Comparison of Soil Analysis and Metal Build-Up in Plant}

In order to evaluate the relation between plant absorption of $\mathrm{Fe}, \mathrm{Mn}, \mathrm{Zn}$, and $\mathrm{Cu}$ and the levels of such elements in soil, a simple correlation matrix (Table 7) was made. Initially, with the exception of $\mathrm{Cu}$ in grains, all of the elements presented a significant degree of correlation with one of the soil extractions, independently of the plant part analyzed.

Table 7 Linear correlation coefficients $(r)$ between $\mathrm{Fe}, \mathrm{Mn}, \mathrm{Zn}$, and $\mathrm{Cu}$ accumulated in maize (grain and leaves) and those obtained by sequential extraction or single extraction (Mehlich 1 and DTPA) considering all data or the type of sewage sludge used

\begin{tabular}{|c|c|c|c|c|c|c|c|c|c|}
\hline & & \multicolumn{2}{|l|}{$\mathrm{Mn}$} & \multicolumn{2}{|l|}{$\mathrm{Fe}$} & \multicolumn{2}{|l|}{$\mathrm{Zn}$} & \multicolumn{2}{|l|}{$\mathrm{Cu}$} \\
\hline & & Leaves & Grain & Leaves & Grain & Leaves & Grain & Leaves & Grain \\
\hline \multicolumn{10}{|l|}{ Franca } \\
\hline Franca & Phase 1 & 0.19 & $0.91 *$ & 0.41 & $0.91 *$ & $0.95 * *$ & $0.97 * *$ & 0.02 & 0.17 \\
\hline Barueri & Phase 1 & 0.53 & 0.34 & 0.74 & 0.79 & $0.94 * *$ & $0.90 *$ & $0.93 * *$ & -0.28 \\
\hline All & Phase 1 & 0.33 & $0.74 * *$ & 0.40 & $0.72 * *$ & $0.95 * *$ & $0.86^{* *}$ & 0.59 & -0.19 \\
\hline Franca & Phase 2 & -0.16 & 0.41 & $0.86^{*}$ & 0.47 & -0.54 & -0.72 & $0.96 * *$ & 0.49 \\
\hline Barueri & Phase 2 & 0.76 & -0.23 & 0.82 & 0.76 & 0.59 & 0.83 & 0.73 & 0.28 \\
\hline All & Phase 2 & 0.27 & 0.00 & $0.67^{*}$ & 0.57 & 0.35 & 0.24 & $0.63^{*}$ & 0.28 \\
\hline Franca & Phase 3 & 0.62 & 0.40 & 0.79 & 0.70 & - & - & 0.48 & 0.42 \\
\hline Barueri & Phase 3 & 0.82 & -0.12 & 0.64 & 0.48 & - & - & $0.88^{*}$ & -0.43 \\
\hline All & Phase 3 & $0.70^{*}$ & 0.26 & 0.30 & 0.43 & - & - & 0.56 & -0.27 \\
\hline Franca & Phase 4 & $0.90 *$ & 0.65 & 0.25 & $0.88 *$ & $0.90 *$ & 0.72 & 0.58 & 0.40 \\
\hline Barueri & Phase 4 & 0.54 & $0.86^{*}$ & 0.36 & $0.87 *$ & -0.06 & 0.13 & 0.33 & 0.72 \\
\hline All & Phase 4 & $0.80 * *$ & $0.58^{*}$ & 0.37 & $0.65^{*}$ & 0.04 & 0.27 & 0.42 & 0.57 \\
\hline Franca & Phase 5 & -0.04 & 0.37 & 0.37 & -0.17 & 0.18 & -0.05 & $0.92 * *$ & 0.58 \\
\hline Barueri & Phase 5 & 0.25 & -0.11 & 0.62 & -0.14 & $0.86^{*}$ & 0.79 & 0.80 & -0.73 \\
\hline All & Phase 5 & -0.03 & 0.08 & 0.34 & -0.07 & 0.20 & 0.04 & 0.56 & -0.25 \\
\hline Franca & $\mathrm{P} 1+\mathrm{P} 2^{1}$ & -0.01 & 0.68 & 0.76 & 0.72 & 0.65 & 0.53 & 0.58 & 0.41 \\
\hline Barueri & $\mathrm{P} 1+\mathrm{P} 2$ & 0.77 & -0.17 & 0.80 & 0.79 & $0.93 * *$ & $0.92 * *$ & $0.93 * *$ & -0.26 \\
\hline All & $\mathrm{P} 1+\mathrm{P} 2$ & 0.30 & 0.13 & 0.57 & $0.65^{*}$ & $0.92 * *$ & $0.82 * *$ & $0.65^{*}$ & -0.15 \\
\hline Franca & $\mathrm{P} 1+\mathrm{P} 3^{\mathrm{b}}$ & 0.65 & 0.61 & 0.55 & $0.88^{*}$ & $0.95 * *$ & $0.97 * *$ & 0.31 & 0.34 \\
\hline Barueri & $\mathrm{P} 1+\mathrm{P} 3$ & $0.88^{*}$ & 0.01 & 0.71 & 0.68 & $0.94 * *$ & $0.90^{*}$ & $0.91^{*}$ & -0.37 \\
\hline All & $\mathrm{P} 1+\mathrm{P} 3$ & $0.75^{*}$ & 0.44 & 0.37 & $0.61 *$ & $0.95 * *$ & $0.86^{* *}$ & $0.58^{*}$ & -0.24 \\
\hline Franca & $\mathrm{P} 1+\mathrm{P} 2+\mathrm{P} 3^{3}$ & 0.65 & 0.83 & 0.77 & 0.72 & 0.65 & 0.53 & 0.54 & 0.43 \\
\hline Barueri & $\mathrm{P} 1+\mathrm{P} 2+\mathrm{P} 3$ & 0.82 & -0.17 & 0.78 & 0.74 & $0.93 * *$ & $0.92 * *$ & $0.91^{*}$ & -0.35 \\
\hline All & $\mathrm{P} 1+\mathrm{P} 2+\mathrm{P} 3$ & $0.62 *$ & 0.25 & 0.52 & $0.62 *$ & $0.92 * *$ & $0.82 * *$ & $0.61 *$ & -0.22 \\
\hline Franca & Mehlich 1 & 0.54 & $0.94 * *$ & 0.28 & $0.92 * *$ & $0.98 * *$ & $0.96 * *$ & 0.37 & 0.37 \\
\hline Barueri & Mehlich 1 & 0.55 & 0.68 & 0.67 & 0.79 & $0.97 * *$ & $0.91 *$ & $0.89^{*}$ & -0.35 \\
\hline All & Mehlich 1 & 0.57 & $0.81 * *$ & 0.37 & $0.76^{* *}$ & $0.96 * *$ & $0.88 * *$ & 0.53 & -0.22 \\
\hline Franca & DTPA & 0.72 & 0.79 & 0.31 & $0.91 *$ & $0.98 * *$ & $0.93 * *$ & 0.36 & 0.31 \\
\hline Barueri & DTPA & 0.64 & 0.59 & 0.55 & 0.82 & $0.97 * *$ & $0.92 * *$ & $0.91 *$ & -0.34 \\
\hline All & DTPA & $0.70 *$ & $0.70 * *$ & 0.39 & $0.85 * *$ & $0.97 * *$ & $0.88 * *$ & 0.56 & -0.22 \\
\hline
\end{tabular}

$* P<0.05, * * P<0.01$

${ }^{\text {a }}$ Phase $1+$ Phase 2

${ }^{\mathrm{b}}$ Phase $1+$ Phase 3

${ }^{\mathrm{c}}$ Phase $1+$ Phase $2+$ Phase 3 
In all of the cases, the sequential extraction phase always presented a significant correlation with the absorption of the analyzed metals by the plant.

In relation to the sewage sludge type (Table 7), the correlation coefficients $(r)$ values increased, except for $\mathrm{Cu}$ in grains.

\section{Conclusion}

This work evidenced that after 5 years of soil amendment with sewage sludge in field experiment:

1. among the elements studied, only the concentrations of $\mathrm{Mn}, \mathrm{Fe}, \mathrm{Zn}$, and $\mathrm{Cu}$ increased significantly in maize grains and leaves due to the doses of sewage sludge applied;

2. most of the studied metals showed a significant increase in the labile Phases (Phase 1, 2, and 3) due to increasing rates of applied sewage sludge;

3. the single extractants and the most available phases of the sequential extraction technique correlated significantly;

4. the application of sewage sludge changed the humic fraction distribution in soil, mainly increasing the humin concentration according to the humic distribution of the type of the sewage sludge used, either industrial or domestic;

5. the chemical properties related to soil fertility, like $\mathrm{P}$ and $\mathrm{N}$ contents and CEC, improved with the use of sewage sludge as a soil amendment;

6. the 2006 Brazilian legislation on sewage sludge application in agriculture, based on sewage sludge nitrogen content and the nitrogen requirement of the cultivated crop, would be the safest and recommended way to use this residue as a soil amendment.

Acknowledgements The authors are grateful to the National Council for Scientific and Technological Development (CNPq), José Bonifácio University Foundation (FUJB), and Foundation for the Support of Research of the State of Rio de Janeiro (FAPERJ) for the grants and to CNPq, FAPERJ, and EMBRAPA for the funding support.

\section{References}

Abreu, C. A., de Raij, B., van Abreu, M. F., \& de González, A. P. (2005). Routine soil testing to monitor heavy metals and boron. Science in Agriculture, 62, 564-571.
Alva, A. K., Sumner, M. E., \& Miller, W. P. (1991). Chemical effects of repeated equilibrations of variable-charge soils with phosphogypsum solution. Soil Science Society of America Journal, 55, 357-361.

Antoniadis, V. (2008). Sewage sludge application and soil properties effects on short-term zinc leaching in soil columns. Water, Air, and Soil Pollution, 190(1-4), 35-43. doi:10.1007/s11270-007-9577-8.

Ashworth, D. J., \& Alloway, B. J. (2007). Complexation of copper by sewage sludge-derived dissolved organic matter: Effects on soil sorption behaviour and plant uptake. Water, Air, and Soil Pollution, 182(1-4), 187196. doi:10.1007/s11270-006-9331-7.

Brofas, G., Michopoulos, P., \& Alifragis, D. (2000). Sewage sludge as an amendment for calcareous bauxite mine spoils reclamation. Journal of Enviromental Quality, 29, 811-816.

Candelaria, L. M., \& Chang, A. C. (1997). Cadmium activity solution speciation and solid phase distribution of $\mathrm{Cd}$ in cadmium nitrate and sewage sludge treated soil systems. Soil Science, 162, 722-732.

Canellas, L. P., de Santos, G. A., Rumjanek, U. M., Moraes, A. A., \& Gurid, F. (2001). Distribution of the organic matter and humic acid characteristics in soils with addition of residues of urban origin. Pesquisa Agropecuária Brasileira, 36, 1529-1538.

Cattelan, A. J., \& Vidor, C. (1990). Crop systems and the soil microbial population. Revista Brasileira de Ciência do Solo, 14, 125-132.

CETESB (1999). Aplicação de lodos de sistemas de tratamento biológico em áreas agrícolas - critérios para projeto e operação.(p. 4230). São Paulo, Brazil: CETESB.

D’Amore, J. J., Al-Abed, S. R., Scheckel, K. G., \& Ryan, J. A. (2005). Methods for speciation of metals in soils. A Review. Journal of Environmental Quality, 34, 17071745.

Das, A. K., Chakraborty, R., Cervera, M. L., \& de la Guardia, M. (1995). Metal speciation in solid matrices. Talanta, 42, 1007-1030.

de Maria, I. C., Rossetto, R., Ambrosano, E. J., de Castro, O. M., \& Neptune, A. M. L. (1993). Effect of several calcium sources on cation leaching using soil columns. Science in Agriculture, 50, 87-98.

EMBRAPA (1997). Centro Nacional de Pesquisas de Solos. Manual de métodos de análises de solo (2and ed.). Rio de Janeiro: Centro Nacional de Pesquisa de Solos.

European Environment Agency (1997). Sludge treatment and disposal: management approaches and experiences. Copenhagen: EEA.

Fernandes, S. A. P., Bettiol, W., \& Cerri, C. C. (2005). Effect of sewage sludge on microbial biomass, basal respiration, metabolic quotient and soil enzymatic activity. Applied Soil Ecology, 30, 65-77.

Fialho, J. F., Borges, A. C., \& Barros, N. F. (1991). Type of vegetation on chemical biomass, basal respiration, metabolic activity in a dystrophic red-yellow latosol. Revista Brasileira de Ciência do Solo, 15, 21-28.

Fuentes, A., Llorens, M. L., Saez, J., Soler, A., Aguilar, M. I., Ortuno, J. F., et al. (2004). Simple and Sequential extractions of heavy metals from different sewage sludges. Chemosphere, 54, 1039-1047. 
Giusquiani, P. L., Gigliotti, G., \& Businelli, D. (1992). Mobility of heavy metals in urban waste-amended soils. Journal of Environmental Quality, 21, 330-335.

Hayes, K. F., \& Traina, S. J. (1998). Metal ion speciation and its significance in ecosystem health. In P.M. Huang (Ed.), Soil Chemistry and Ecosystems Health (pp. 45-84). Madison: SSSA.

Hseu, Z.-Y. (2006). Extractability and bioavailability of zinc over time in three tropical soils incubated with biosolids. Chemosphere, 63, 762-771.

Kabata-Pendias, A., \& Pendias, H. (2001). Trace elements in soils and plants (3rd ed.). Boca Raton: CRC.

Kidd, P. S., Domınguez-Rodriguez, M. J., Diez, J., \& Monterroso, C. (2007). Bioavailability and plant accumulation of heavy metals and phosphorus in agricultural soils amended by long-term application of sewage sludge. Chemosphere, 66, 1458-1467.

Kononova, M. M. (1984). Organic matter and soil fertility. Soviet Soil Science, 16, 71-86.

Kot, A., \& Namiesnik, J. (2000). The role of speciation in analytical chemistry. Trends in Analytical Chemistry, 19, 69-79.

Mantovi, P., Baldoni, G., \& Toderi, G. (2005). Reuse of liquid, dewatered, and composted sewage sludge on agricultural land: effects of long-term application on soil and crop. Water Research, 39, 289-296.

Mbila, M. O., Thompson, M. L., Mbagwu, J. S. C., \& Laird, D. A. (2001). Distribution and movement of sludge-derived trace metals in selected Nigerian soils. Journal of Environmental Quality, 30, 1667-1674.

McBride, M. B. (2003). Toxic Metals in sewage sludgeamended soils: has promotion of beneficial use discounted the risk. Advances in Environmental Research, 8, 5-19.

McLaren, R. G., Clucas, L. M., \& Taylor, M. D. (2005). Leaching of macronutrients and metals from undisturbed soils treated with metal-spiked sewage sludge. 3. Distribution of residual metals. Australian Journal of Soil Research, 43(2), 159-170.

Mendoza, J., Garrido, T., Castillo, G., \& San Martin, N. (2006). Metal availability and uptake by sorghum plants grown in soils amended with sludge from different treatments. Chemosphere, 65, 2304-2312.

Morrow, D. A., Gintautas, P. A., Weiss, A. D., Piwoni, M. D., \& Bricka, R. M. (1996). Metals speciation in soils: a review. Vicksburg: U.S. Army Corps of Engineer.

Obbard, J. P., Sauerbeck, D. R., \& Jones, K. C. (1993). Rhizobium leguminosarum bv. trifolii in soils amended with heavy metal contaminated sewage sludge. Soil Biology and Biochemistry, 25, 227-231.

Oliveira, F. C., Mattiazzo, M. E., Marciano, C. R., \& Abreu Junior, C. H. (2002). Movement of heavy metals in an Oxisol fertilized with municipal solid waste compost. Pesquisa Agropecuária Brasileira, 37 (12), 1787-1793.

Paramasivam, S., Sajwan, K. S., \& Alva, A. K. (2006). Incinerated sewage sludge products as amendments for agricultural soils: leaching and plant uptake of trace elements. Water, Air, and Soil Pollution, 171(1-4), 273290. doi:10.1007/s11270-005-9042-5.
Perez, D. V., Alcantara, S., Ribeiro, C. C., Pereira, R. E., Fontes, G. C., Wasserman, M. A., et al. (2007). Composted municipal waste effects on chemical properties of a Brazilian soil. Bioresource Technology, 98(3), 525-533.

Rocha, G. N., Gonçalves, J. L. M., \& Moura, I. M. (2004). Changes in soil fertility and growth of an Eucalyptus grandis plantation fertilized with biosolid. Revista Brasileira de Ciência do Solo, 28, 623-639.

Sanchez-Monedero, M. A., Mondini, C., de Nobili, M., Leita, L., \& Roig, A. (2004). Land application of biosolids. Soil response to different stabilization degree of the treated organic matter. Waste Management, 244, $325-332$.

SAS (2003). SAS System for Windows, v.9.1.3 Service Pack 3. Cary: SAS Institute.

Sastriques, F. O. (1982). La materia organica de los suelos y el humus de los suelos de Cuba. La Habana: Editora de la Academia de Ciencia de Cuba.

Sauve, S., Dumestre, A., Mcbride, M., \& Hendershot, W. (1998). Derivation of soil quality criteria using predicted chemical speciation of $\mathrm{Pb} 2+$ and $\mathrm{Cu} 2+$. Environmental Toxicology and Chemistry, 17, 1481-1489.

Shaw, A. J. (1989). Heavy metal tolerance in plants: evolutionary aspects. Boca Raton, USA: CRC.

Shevtsova, L. K. (1972). Methods of studying organic matter in continuously fertilized soils. Soviet Soil Science, 4, 479490.

Silva, C. A., Rangel, O. J. P., Dynia, J. F., Bettiol, W., \& Manzatto, C. V. (2006). Heavy metals availability for corn cultivated in a latosol sucessively amended with sewage sludges. Revista Brasileira de Ciencia do Solo, 30(2), 353-364.

Stabnikova, O., Goh, W. K., Ding, H. B., Tay, J. H., \& Wang, J. Y. (2005). The use of sewage sludge and horticultural waste to develop artificial soil for plant cultivation in Singapore. Bioresource Technology, 96(9), 1073-1080.

Strobel, B. W. (2001). Influence of vegetation on lowmolecular weight carboxylic acids in soil solution-a review. Geoderma, 99, 169-198.

Stumm, W., \& Morgan, J. J. (1996). Aquatic chemistry: chemical equilibria and rates in natural waters (3rd ed.). New York: Wiley.

Su, D. C., \& Wong, J. W. C. (2003). Chemical speciation and phytoavailability of $\mathrm{Zn}, \mathrm{Cu}, \mathrm{Ni}$, and $\mathrm{Cd}$ in soil amended with fly ash-stabilized sewage sludge. Environment. International, 29, 895-900.

Tan, K. H. (2003). Humic Matter in Soil and the Environment: Principles and Controversies. New York: Marcel Dekker.

Tiller, K. G. (1989). Heavy metal pollution of soils. Advances in Soil Science, 9, 113-141.

Tipping, E. (2002). Cation binding by humic substances. Cambridge: University Press.

Toribio, M., \& Romanya, J. (2006). Leaching of heavy metals $(\mathrm{Cu}, \mathrm{Ni}$ and $\mathrm{Zn})$ and organic matter after sewage sludge application to Mediterranean forest soils. Science of the Total Environment, 36(3), 11-21.

Udom, B. E., Mbagwu, J. S., Adesodun, J. K., \& Agbim, N. N. (2004). Distributions of zinc, copper, cadmium and lead in a tropical ultisol after long-term disposal of 
sewage sludge. Environment International, 30(4), 467470.

Wang, M.-J. (1997). Land application of sewage sludge in China. Science of the Total Environment, 197, 149160 .

Wang, M. C., \& Huang, P. M. (2003). Cleavage and polycondensation of pyrogallol and glycine catalyzed by natural soil clays. Geoderma, 112, 31-50.
Wasserman, M. A., Viana, A. G., Bartoly, F., Perez, D. V., Ruas Rochedo, E., Wasserman, J. C., et al. (2005). Biogeochemical behavior of $90 \mathrm{Sr}$ and $137 \mathrm{Cs}$ in tropical soil. Radioprotection, 40, S135-S142.

Zech, W., Senesi, N., Guggenberger, G., Kaiser, K., Lehman, J., Miano, T. M., et al. (1997). Factors controlling humification and mineralization of soil organic matter in the tropics. Geoderma, 79, 117-161. 